\title{
Bartonella quintana, an Unrecognized Cause of Infective Endocarditis in Children in Ethiopia
}

\author{
Diana Tasher, Alona Raucher-Sternfeld, Akiva Tamir, Michael Giladi, Eli Somekh
}

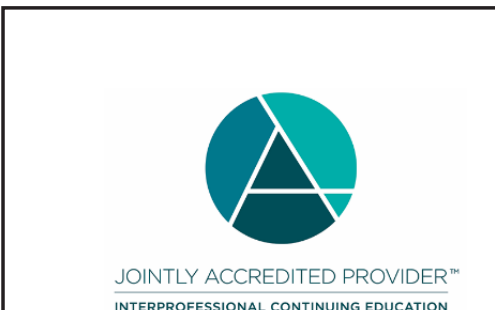

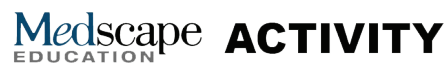

In support of improving patient care, this activity has been planned and implemented by Medscape, LLC and Emerging Infectious Diseases. Medscape, LLC is jointly accredited by the Accreditation Council for Continuing Medical Education (ACCME), the Accreditation Council for Pharmacy Education (ACPE), and the American Nurses Credentialing Center (ANCC), to provide continuing education for the healthcare team.

Medscape, LLC designates this Journal-based CME activity for a maximum of 1.00 AMA PRA Category 1 Credit(s) ${ }^{\mathrm{TM}}$. Physicians should claim only the credit commensurate with the extent of their participation in the activity.

All other clinicians completing this activity will be issued a certificate of participation. To participate in this journal CME activity: (1) review the learning objectives and author disclosures; (2) study the education content; (3) take the post-test with a $75 \%$ minimum passing score and complete the evaluation at http://www.medscape.org/journal/eid; and (4) view/print certificate. For CME questions, see page 1439.

Release date: July 14, 2017; Expiration date: July 14, 2018

Learning Objectives

Upon completion of this activity, participants will be able to:

- Distinguish features of infection with Bartonella quintana.

- Identify the country of origin of children in the current case series of Bartonella endocarditis.

- $\quad$ Assess presenting symptoms of Bartonella endocarditis among children.

- Analyze clinical findings associated with Bartonella endocarditis among children.

\section{CME Editor}

Claudia Chesley, BA, Technical Writer/Editor, Emerging Infectious Diseases. Disclosure: Claudia Chesley, BA, has disclosed no relevant financial relationships.

\section{CME Author}

Charles P. Vega, MD, Health Sciences Clinical Professor, UC Irvine Department of Family Medicine; Associate Dean for Diversity and Inclusion, UC Irvine School of Medicine, Irvine, California, USA. Disclosure: Charles P. Vega, MD, has disclosed the following financial relationships: served as an advisor or consultant for McNeil Consumer Healthcare; served as a speaker or a member of a speakers bureau for Shire Pharmaceuticals.

\section{Authors}

Disclosures: Diana Tasher, MD; Alona Raucher-Sternfeld, MD; Akiva Tamir, MD; Michael Giladi, MD; and Eli Somekh, MD, have disclosed no relevant financial relationships.

Bartonella quintana endocarditis, a common cause of culturenegative endocarditis in adults, has rarely been reported in children. We describe 5 patients $7-16$ years of age from Ethiopia with heart defects and endocarditis; 4 cases were caused by

Author affiliations: Tel Aviv University Sackler School of Medicine,

Tel Aviv, Israel (D. Tasher, A. Raucher-Sternfeld, A. Tamir,

M. Giladi, E. Somekh); Wolfson Medical Center, Holon, Israel

(D. Tasher, A. Raucher-Sternfeld, A. Tamir, E. Somekh); Tel Aviv

Sourasky Medical Center, Tel Aviv (M. Giladi); European

Paediatric Association-Union of National European Paediatric

Societies and Associations, Berlin, Germany (E. Somekh)

DOI: https://doi.org/10.3201/eid2308.161037 infection with $B$. quintana and 1 by Bartonella of undetermined species. All 5 patients were afebrile and oligosymptomatic, although 3 had heart failure. C-reactive protein was normal or slightly elevated, and erythrocyte sedimentation rate was high. The diagnosis was confirmed by echocardiographic demonstration of vegetations, the presence of high Bartonella IgG titers, and identification of $B$. quintana DNA in excised vegetations. Embolic events were diagnosed in 2 patients. Our data suggest that $B$. quintana is not an uncommon cause of native valve endocarditis in children in Ethiopia with heart defects and that possible $B$. quintana infection should be suspected and pursued among residents of and immigrants from East Africa, including Ethiopia, with culture-negative endocarditis. 
$\mathrm{B}$ lood culture-negative endocarditis accounts for $2.5 \%$ $31 \%$ of all cases of endocarditis (1). Bartonella spp. (most commonly B. henselae and B. quintana) are among the most common causes of blood culture-negative endocarditis, being responsible for $9.5 \%-28.4 \%$ of all cases $(2,3)$. The literature regarding Bartonella endocarditis among children describes 1 microbiologically confirmed case caused by $B$. quintana (4) and 8 cases caused by $B$. henselae (5-12). In this case series, we describe 5 patients, 7-16 years of age, from Ethiopia who were referred to our center in Israel for heart surgery and diagnosed with endocarditis caused by B. quintana (4 cases) or Bartonella of an undetermined species (1 case).

\section{Materials and Methods}

Wolfson Medical Center in Holon, Israel, provides cardiothoracic care to children from developing regions, such as Africa, Palestinian Authority, and South America, who are referred for care through the Save a Child's Heart fund activity (13). Each year, doctors in the Center perform heart surgery on $\approx 200$ children from developing countries. After the unexpected diagnosis of $B$. quintana endocarditis in this group of children, we reviewed the presurgical cases of infective endocarditis in children referred for heart surgery during 2006-2015.

Before surgery, we conducted a thorough work-up on all patients with endocarditis, including several blood cultures and serologic testing for Bartonella, Legionella, and Brucella spp. and for Q fever (Coxiella burnetii infection). In addition, for most patients, we performed microbiologic studies of specimens obtained during cardiac surgery. We performed and interpreted enzyme immunoassays that have been shown to be $98 \%$ specific for detection of $B$. henselae $\operatorname{IgM}$ and $\operatorname{IgG}(14,15)$. We also performed serial dilutions to determine final serum titers.

Similar to other serologic assays used for the diagnosis of Bartonella infections $(16,17)$, the enzyme immunoassay used in this study demonstrated high cross-reactivity between $B$. quintana and B. henselae (M. Giladi, unpub. data). Thus, we presented serologic results as Bartonella sp. IgG and IgM, without species identification. We also performed a genus-specific amplification assay of a 588bp fragment of the Bartonella riboflavin synthase gene as previously reported (18). For species identification, we sequenced the PCR product and submitted it to a BLAST search (https://blast.ncbi.nlm.nih.gov/Blast.cgi). We considered patients to have endocarditis only after they were determined to fulfill the Duke criteria (19).

\section{Results}

From January 1, 2006, through December 31, 2015, a total of 574 children from Africa underwent cardiac surgery, catheterization, or both at Wolfson Medical Center.
During this time, 7 (1.2\%) of the 574 children were diagnosed with infective endocarditis before surgery. The most frequent cause of endocarditis was $B$. quintana infection, which was diagnosed in 4/7 children. The 3 other endocarditis cases were caused by undetermined Bartonella spp. infection in an 11-year-old boy from Ethiopia, Streptococcus viridans infection in a 2-year-old boy from Zanzibar, and Q fever in a 7-year-old girl from Kenya. All patients with Bartonella endocarditis were from Ethiopia, where they lived in poor, crowded conditions. The clinical details of the children with Bartonella endocarditis follow.

\section{Cases}

\section{Patient A}

An asymptomatic 7-year-old girl from Jimma, Ethiopia, with patent ductus arteriosus was referred to the Wolfson Medical Center. At admission, she was afebrile and in good general condition. Her physical examination revealed a grade $2 / 6$ continuous cardiac murmur and splenomegaly but no stigmata of infective endocarditis. Transthoracic echocardiogram (TTE) revealed thickening of the pulmonary valve and the presence of a large (1.1 $\mathrm{cm}$ in diameter) mobile mass attached to the middle of the main pulmonary artery and several small masses attached to the pulmonic valve cusps, consistent with vegetations. The main laboratory results were a high erythrocyte sedimentation rate (ESR) and an only slightly elevated CRP (Table).

We obtained blood samples for cultures and then initiated empirical therapy with doxycycline and ceftriaxone for presumed common and culture-negative endocarditis pathogens. The serologic test result for Bartonella spp. was positive (IgG titer of 1:1,600), but the test result for IgM was negative (Table). Thus, we initiated treatment with intravenous gentamicin ( $3 \mathrm{mg} / \mathrm{kg}$ bodyweight $1 \times / \mathrm{d})$ and oral doxycycline ( $2 \mathrm{mg} / \mathrm{kg}$ bodyweight every $12 \mathrm{~h}$ ) for Bartonella endocarditis $(20,21)$. After 2 weeks of treatment, the patient underwent surgical repair of her heart defect. The vegetations were excised from the main pulmonary artery and the pulmonic valve cusps, a perforation that was revealed in the right pulmonary valve cusp was repaired, and the patent ductus arteriosus was closed. The child had an uneventful postoperative course. PCR testing confirmed the presence of B. quintana DNA in the excised vegetation. The child completed a 2-week course of gentamicin and a 5 -week course of oral doxycycline and returned to Ethiopia in good condition.

\section{Patient B}

A 12-year-old girl from Jimma was admitted for the correction of mitral regurgitation due to rheumatic heart 
Table. Features for children from Ethiopia with Bartonella quintana endocarditis*

\begin{tabular}{|c|c|c|c|c|c|c|c|c|c|c|}
\hline \multirow{2}{*}{$\begin{array}{l}\text { Patient, } \\
\text { age, y/sex }\end{array}$} & \multirow{2}{*}{$\begin{array}{l}\text { Echo } \\
\text { finding }\end{array}$} & \multirow{2}{*}{$\begin{array}{l}\text { Underlying } \\
\text { condition }\end{array}$} & \multicolumn{2}{|c|}{ Phenomena } & \multirow[b]{2}{*}{ Microbiologic evidence } & \multirow{2}{*}{$\begin{array}{l}\mathrm{CRP}, \\
\mathrm{mg} / \mathrm{dL}\end{array}$} & \multirow{2}{*}{$\begin{array}{l}\mathrm{ESR}, \\
\mathrm{mm} / \mathrm{h}\end{array}$} & \multirow{2}{*}{$\begin{array}{l}\text { Leuk/ } \\
\mathrm{mm}^{3}\end{array}$} & \multirow{2}{*}{$\begin{array}{l}\mathrm{Hb}, \\
\mathrm{g} / \mathrm{dL}\end{array}$} & \multirow{2}{*}{$\begin{array}{c}\text { Platelets/ } \\
\mathrm{mm}^{3} \dagger\end{array}$} \\
\hline & & & Vascular & Immunologic & & & & & & \\
\hline$A, 7 / F$ & $\begin{array}{c}\text { Several } \\
\text { vegetations } \\
(11 \mathrm{~mm}) \text { on } \\
\text { pulmonary } \\
\text { valve }\end{array}$ & $\mathrm{CHD}$ & No & $\begin{array}{c}\text { RF Ab, } 189 \\
\text { IU/mL }\end{array}$ & $\begin{array}{c}\text { Bartonella IgG titer } \\
\text { 1:1,600, IgM neg; } \\
\text { excised vegetation PCR- } \\
\text { neg for Coxiella burnetii, } \\
\text { PCR-pos for } B \text {. } \\
\text { quintanał }\end{array}$ & 1.7 & 128 & 3,500 & 8.5 & 150,000 \\
\hline $\mathrm{B}, 12 / \mathrm{F}$ & $\begin{array}{l}\text { Vegetation } \\
(7 \mathrm{~mm}) \text { on } \\
\text { mitral valve }\end{array}$ & RHD & No & $\begin{array}{c}\mathrm{RF} A b,<10 \\
\mathrm{IU} / \mathrm{mL}\end{array}$ & $\begin{array}{c}\text { Bartonella IgG titer } \\
\text { 1:100, IgM neg; excised } \\
\text { vegetation PCR-neg for } \\
\text { C. burnetii, PCR-pos for } \\
\text { B. quintanał } \\
\end{array}$ & 0.7 & 50 & 5,700 & 10.3 & 310,000 \\
\hline $\mathrm{C}, 16 / \mathrm{F}$ & $\begin{array}{c}\text { Two } \\
\text { vegetations } \\
(5 \mathrm{~mm}) \text { on } \\
\text { aortic valve }\end{array}$ & RHD & $\begin{array}{l}\text { Emboli to } \\
\text { spleen }\end{array}$ & $\begin{array}{c}\text { GN; } 16 \text { Osler } \\
\text { nodes }\end{array}$ & $\begin{array}{c}\text { Bartonella IgG titer } \\
\text { 1:12,800 (10 wks after } \\
\text { surgery: } 1: 6,400) \\
\text { excised vegetation PCR- } \\
\text { neg for } C \text {. burnetii, PCR- } \\
\text { pos for } B \text {. quintanał }\end{array}$ & 4.2 & 150 & 6,900 & 7.8 & 334,000 \\
\hline $\mathrm{D}, 9 / \mathrm{F}$ & $\begin{array}{c}\text { Several } \\
\text { vegetations } \\
(10 \mathrm{~mm} \text { and } \\
20 \mathrm{~mm}) \text { on } \\
\text { aortic valve }\end{array}$ & $\mathrm{CHD}$ & CVA & $\begin{array}{c}\text { RF Ab, } 25 \\
\text { IU } / \mathrm{mL}\end{array}$ & $\begin{array}{c}\text { Bartonella IgG titer } \\
1: 6,400 \text { ( } 5 \text { wks after } \\
\text { surgery: } 1: 1,600) \\
\text { excised vegetation PCR- } \\
\text { neg for } C \text {. burnetii, PCR- } \\
\text { pos for } B \text {. quintanał }\end{array}$ & 1.5 & 44 & 6,100 & 11.7 & 189,000 \\
\hline $\mathrm{E}, 11 / \mathrm{M}$ & $\begin{array}{l}\text { Vegetation } \\
(14 \mathrm{~mm}) \text { on } \\
\text { aortic valve } \\
\end{array}$ & $\mathrm{CHD}$ & No & $\begin{array}{c}\text { RF Ab, 2,560 } \\
\text { IU/mL }\end{array}$ & $\begin{array}{c}\text { Bartonella IgG titer } \\
1: 6,400 ; \text { C. burnetii IgM } \\
\text { neg }\end{array}$ & 2.0 & 110 & 9,100 & 11.8 & 264,000 \\
\hline \multicolumn{11}{|c|}{ 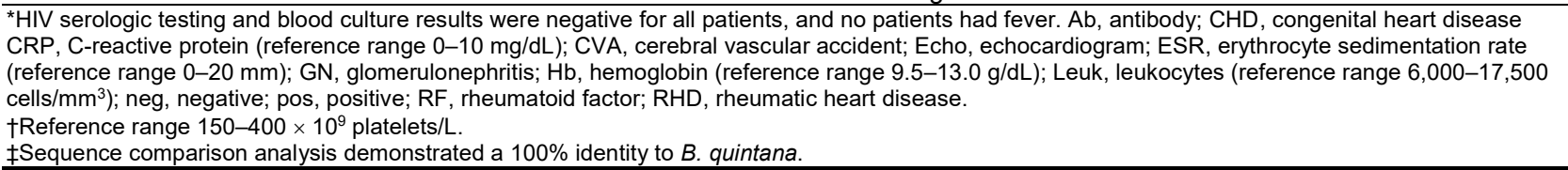 } \\
\hline
\end{tabular}

disease, which had been diagnosed 4 months earlier due to symptoms of congestive heart failure. On physical examination, she was afebrile and exhibited tachypnea and orthopnea. Cardiac examination revealed a grade 4/6 harsh systolic ejection murmur and a grade $2 / 4$ diastolic rumble at the apex. Physical findings were otherwise unremarkable and showed no stigmata of infective endocarditis. TTE revealed the presence of a 7-mm mobile mass, consistent with vegetation, attached to the mitral chordae. Main laboratory results were high erythrocyte sedimentation rate (ESR) and an only slightly elevated CRP (Table).

We initiated empirical therapy with doxycycline and ceftriaxone, and after serologic results were received, we initiated treatment with gentamicin and oral doxycycline for Bartonel$l a$ endocarditis. After 2 weeks of treatment with doxycycline, the child underwent mitral valvuloplasty; she had an uneventful postoperative course. PCR testing confirmed the presence of $B$. quintana DNA in the excised vegetations. The child completed a 6-week course of oral doxycycline and a 1-week course of gentamicin (during the first week of doxycycline treatment) and returned to Ethiopia in good condition.

\section{Patient C}

A 16-year-old girl from Jimma was admitted for surgical repair of mitral and aortic valve disease due to rheumatic heart disease that had been diagnosed when she was 12 years of age. During the previous year, she had had several heart failure-related hospitalizations. At admission, she was afebrile and exhibited orthopnea and dyspnea. Cardiac examination revealed a grade $3 / 4$ diastolic murmur, and abdominal examination showed liver enlargement. Physical findings were otherwise unremarkable, with no stigmata of infective endocarditis. TTE revealed 2 vegetations (5-mm diameter) attached to the noncoronary aortic valve cusp. As with the previous patients, her laboratory results showed high ESR and only slightly elevated CRP (Table).

After receiving the serologic test results, we initiated treatment with gentamicin and doxycycline. After 2 weeks of treatment, painful reddish lesions suggestive of Osler nodes developed on the patient's palms, and her spleen was enlarged $4 \mathrm{~cm}$ below the costal margin. Repeated TTE revealed a single vegetation. Abdominal ultrasonography showed enlarged spleen $(14.5 \mathrm{~cm}$ in length) with infarcts compatible with emboli. The patient underwent surgical repair of her mitral and aortic valves. PCR testing confirmed the presence of $B$. quintana DNA in the excised vegetation. The patient completed a 12-week course of oral doxycycline and a 2-week course of gentamicin (during the first 2 weeks of doxycycline treatment). Six months after surgery she was asymptomatic. 


\section{Patient D}

A 9-year-old girl from Addis Ababa, Ethiopia, was referred for surgical repair of a congenital heart defect. One year before admission, she had a history of febrile illness accompanied by left-sided weakness. The patient was diagnosed in Ethiopia with a large patent ductus arteriosus and severe aortic regurgitation and was suspected to have infective endocarditis. At admission, she was afebrile but had systolic and diastolic murmurs and hepatosplenomegaly. Neurologic examination revealed left hemiparesis. She had no other stigmata of infective endocarditis. TTE revealed several calcified vegetations (10 $\mathrm{mm}$ and $20 \mathrm{~mm}$ in diameter) attached to the cusps of the aortic valve.

We initiated treatment with gentamicin and oral doxycycline. After receiving treatment for a week, the patient underwent aortic valve replacement, mitral valve repair, and patent ductus arteriosus closure. PCR of the excised aortic valve revealed $B$. quintana DNA. The child had an uneventful postoperative course. She completed a 2-week course of gentamicin and a 10-week course of oral doxycycline.

\section{Patient E}

An 11-year-old boy from Addis Ababa was referred for repair of a large coronary artery fistula. He complained mainly of weakness on exertion and chest pain. Physical examination revealed unremarkable vital signs and temperature, continuous machinery murmur, and splenomegaly but no rash or endocarditis stigmata. An echocardiograph revealed a $14-\mathrm{mm}$ vegetation on the aortic valve. Serologic studies revealed a high IgG titer $(1: 6,400)$ to Bartonella sp.; IgM results were negative. The results of other serologic studies and multiple blood cultures were negative (Table).

We initiated treatment with gentamicin (for 2 weeks) and oral doxycycline (for 3 months). The heart defect was corrected by catheterization without surgery, so we did not have tissue for molecular studies and could not determine the Bartonella species. We followed the child for 5 months in our center; he was asymptomatic, and repeated echocardiography showed gradual regression of the vegetation size until its actual disappearance.

\section{Discussion}

This case series provides detailed information regarding the clinical presentation, course, and outcome of Bartonella endocarditis caused by B. quintana infection in 4 children and by Bartonella of undetermined species in 1 child. Of interest, all 5 children were natives of Ethiopia. When admitted to our medical center, all of the children were afebrile and had nonspecific symptoms, except for heart failure, which was attributed to their previously known heart disease. In 4 of the 5 patients, endocarditis was not suspected on clinical grounds, but we pursued the diagnosis after echocardiographs revealed vegetations. The diagnosis of $B$. quintana endocarditis was confirmed in 4 patients (patients $\mathrm{A}-\mathrm{D}$ ) by identification of B. quintana DNA in excised vegetations or endocardial tissue. The diagnosis was further supported by the presence of Bartonella IgG in these 4 patients, 3 of whom had high titers $(1: 1,600-1: 12,800)$. The fifth patient had Bartonella endocarditis caused by an undetermined species; the diagnosis was based only on serologic test results (IgG titer of 1:6,400) because cardiac tissue was not available for molecular diagnosis. Western blot with cross-absorption studies, a method described by Houpikian and Raoult (22), could have discriminated between B. quintana and B. henselae if it had been applied.

Bartonella spp. are small, gram-negative bacilli whose natural cycle includes a reservoir host, in which Bartonella causes chronic intraerythrocytic bacteremia. In 1993, Bartonella spp. were described as a cause of endocarditis in 2 separate reports and subsequently has become appreciated as a substantial cause of culturenegative endocarditis $(3,23,24)$. Raoult and colleagues have generated several reports on endocarditis caused by Bartonella spp., including several multicenter international studies that involved patients from France, England, and Canada (17,25). Seven Bartonella spp. have been reported to cause infective endocarditis in humans; $>95$ percent of the cases involved B. quintana or B. henselae (17).

This case series of Bartonella endocarditis in children reveals several common characteristics. All cases occurred in preadolescent and adolescent patients; all patients were afebrile, and the main pathophysiologic dysfunction was congestive heart failure. All patients had markedly elevated ESRs but normal or only mildly elevated CRP levels. Echocardiography revealed large and even giant vegetations in most of the patients, and $2(40 \%)$ of the patients had embolic phenomena. Medical treatment consisted of a prolonged course of doxycycline combined with gentamicin during the initial period, as was recommended for adults with Bartonella endocarditis (21). Even though prolonged administration of doxycycline is relatively contraindicated in children $<8$ years of age, we suggested a 5 -week course for the 7-year-old patient (patient A), as recently recommended (20), because of the extent of her valvular disease.

B. quintana is historically known to cause trench fever, a recurrent febrile disease with acute onset characterized by fever and headache. Trench fever was epidemic among troops during World War I, causing millions of casualties. However, after the introduction of louse control measures, the disease was no longer considered a threat. 
Recently, however, trench fever has reemerged, causing bacteremia in homeless persons and persons affected with alcoholism in Europe and North America, where it has now been designated urban trench fever (26). B. quintana is mostly associated with human body lice but has also been found in fleas $(27,28)$. The predisposing factors for B. quintana endocarditis are homelessness, alcoholism, and exposure to body lice (29). None of these risk factors for B. quintana infection were known to exist in the patients in this study.

Patients in this study denied having had lice infestation in the past, and we did not identify body lice, pruritus, or excoriations during the initial physical examinations. However, we believe that detailed and accurate histories regarding lice infestation were lacking, particularly because patients with $B$. quintana endocarditis have probably been infected with $B$. quintana for months or years before hospital admission for endocarditis. We speculate that residence in a developing country with presumably poor hygiene and low socioeconomic status might have exposed the patients in this study to ectoparasite infestations, including body lice, which could have served as a transmitting vector for B. quintana.

In contrast to our report of afebrile patients with sizable vegetations, previous reports of Bartonella endocarditis have described that fever is usually present $(83 \%$ of cases) and that valve destruction is characterized by large calcifications but small vegetations (25). Description of B. quintana endocarditis in children is currently confined to a case in a 13-year-old girl from Senegal with underlying rheumatic heart disease, an insidious afebrile clinical course, and prominent vegetations of the left side of the heart (4). Another 2 children with endocarditis and $B$. quintana-positive serologic test results were included in a series from India, but no clinical or laboratory details were provided (30).

Of the 5 children in our study with Bartonella endocarditis, 4 had involvement of the aortic valve. The predilection for Bartonella spp. to infect the aortic valve has been described (25), but the reason is unknown. Before surgery, 4 of the 5 children fulfilled the Duke criteria for definite infective endocarditis, and the fifth child (patient E) fulfilled criteria for possible endocarditis (Table).

The Duke criteria do not address Bartonella endocarditis specifically, and a definitive diagnosis of Bartonella infection requires positive, high-titer serologic test results; PCR identification of Bartonella sp. DNA in affected tissue or blood; or, on rare occasions, isolation of Bartonella sp. from blood or tissue culture. Recent studies have shown that direct immunofluorescence antibody assays can reliably detect Bartonella IgG, and an IgG titer of $>1: 800$ has a high positive predictive value (95.5\%) for Bartonella infection among patients with endocarditis $(31,32)$. However, in 2015, Edouard et al. (32) reported that an IgG titer of $<800$ does not exclude the diagnosis of Bartonella endocarditis in patients with valvulopathy and that a serologic diagnosis can be confirmed by a positive Western blot result, which they showed exhibited a sensitivity of $100 \%$. Similarly, we showed that high Bartonella IgG titers can be detected by enzyme immunoassay; only 1 patient in our series had IgG titers $<1: 800$. Thus, the enzyme immunoassay has a meaningful role in the diagnosis of Bartonella $\mathrm{sp}$. endocarditis.

Epidemiologic data suggest a north-south gradient distribution in the prevalence of Bartonella endocarditis, from $0 \%$ in Sweden to 3\% in France and Germany and reaching $15.6 \%$ in Algeria and 9.8\% in Tunisia (32). Lice are a well-recognized reservoir of $B$. quintana. Using reverse transcription PCR testing of lice from residents of 9 African countries, Sangaré et al. (33) showed B. quintana DNA was present in $54 \%$ of body and $2 \%$ of head lice, and they found a clear correlation between the presence of $B$. quintana in head and body lice and the degree of country poverty, as determined by the gross domestic product. Bartonella spp. were found among $6(9.2 \%)$ of 65 head lice pools and $1(3.0 \%)$ of 33 clothing lice pools from Jimma (34). These data indicate that B. quintana may be quite abundant in East Africa. However, due to the lack of serologic surveys for Bartonella species in this region, its extent is unknown.

In our series, $B$. quintana was the most frequent causative organism of native valve endocarditis among children from Africa referred to our center for heart surgery. These cases by no means represent the whole spectrum of infective endocarditis in children in Africa, or even Ethiopia, because a selection bias might exist toward cases of nonacute, indolent, infective endocarditis in patients referred for complicated surgeries. However, the predominance of $B$. quintana infection, even in this specific, small subgroup of patients, is quite impressive and may imply a broader role of this microorganism in infective endocarditis cases in children in Ethiopia or Africa as a whole.

In conclusion, B. quintana is a substantial cause of endocarditis in children in Ethiopia with heart disease. Diagnosis may easily be missed because of the afebrile, insidious nature of this disease and the apparent lack of traditional risk factors for Bartonella infections.

\section{Acknowledgment}

We thank Roger Hertz for reviewing the manuscript.

Dr. Tasher is an attending physician in the Pediatric Infectious

Diseases Unit, Wolfson Medical Center, in Holon, Israel.

Her primary research interests include vaccines and 
vaccine-preventable diseases, periodic fever adenitis pharyngitis aphthous ulcer syndrome; neonatal herpes; and zoonotic infections, including Q fever and infections caused by Bartonella spp.

\section{References}

1. Brouqui P, Raoult D. Endocarditis due to rare and fastidious bacteria. Clin Microbiol Rev. 2001;14:177-207. http://dx.doi.org/10.1128/CMR.14.1.177-207.2001

2. Brouqui P, Raoult D. New insight into the diagnosis of fastidious bacterial endocarditis. FEMS Immunol Med Microbiol. 2006;47:113. http://dx.doi.org/10.1111/j.1574-695X.2006.00054.x

3. Fournier PE, Thuny F, Richet H, Lepidi H, Casalta JP, Arzouni JP, et al. Comprehensive diagnostic strategy for blood culture-negative endocarditis: a prospective study of 819 new cases. Clin Infect Dis. 2010;51:131-40. http://dx.doi.org/10.1086/653675

4. Pósfay Barbe K, Jaeggi E, Ninet B, Liassine N, Donatiello C, Gervaix A, et al. Bartonella quintana endocarditis in a child. N Engl J Med. 2000;342:1841-2. http://dx.doi.org/10.1056/ NEJM200006153422418

5. Baorto E, Payne RM, Slater LN, Lopez F, Relman DA, Min KW, et al. Culture-negative endocarditis caused by Bartonella henselae. J Pediatr. 1998;132:1051-4. http://dx.doi.org/10.1016/ S0022-3476(98)70410-X

6. Pitchford CW, Creech CB II, Peters TR, Vnencak-Jones CL. Bartonella henselae endocarditis in a child. Pediatr Cardiol. 2006;27:769-71. http://dx.doi.org/10.1007/s00246-006-1383-3

7. Ghidoni JJ. Role of Bartonella henselae endocarditis in the nucleation of aortic valvular calcification. Ann Thorac Surg. 2004;77:704-6. http://dx.doi.org/10.1016/j.athoracsur.2003. 06.002

8. Walls T, Moshal K, Trounce J, Hartley J, Harris K, Davies G. Broad-range polymerase chain reaction for the diagnosis of Bartonella henselae endocarditis. J Paediatr Child Health. 2006;42:469-71. http://dx.doi.org/10.1111/j.1440-1754. 2006.00900.x

9. Das BB, Wasser E, Bryant KA, Woods CR, Yang SG, Zahn M. Culture-negative endocarditis caused by Bartonella henselae in a child with congenital heart disease. Pediatr Infect Dis J. 2009;28:922-5. http://dx.doi.org/10.1097/

INF.0b013e3181a39e0e

10. Atamanyuk I, Raja SG, Kostolny M. Bartonella henselae endocarditis of percutaneously implanted pulmonary valve. J Heart Valve Dis. 2012;21:682-5.

11. Itoh M, Kann DC, Schwenk HT, Gans HA. Fever and renal failure in a child with DiGeorge syndrome and tetralogy of Fallot. J Pediatric Infect Dis Soc. 2015;4:373-5. http://dx.doi.org/10.1093/ jpids/piv029

12. Sosa T, Goldstein B, Cnota J, Bryant R, Frenck R, Washam M, et al. Melody valve Bartonella henselae endocarditis in an afebrile teen: a case report. Pediatrics. 2016;137:e20151548. http://dx.doi.org/10.1542/peds.2015-1548

13. Ezri T, Sasson L, Houri S, Berlovitz Y, Tamir A. Save a Child's Heart project in Israel. Lancet. 2014;384:1575-6. http://dx.doi.org/ 10.1016/S0140-6736(14)61984-X

14. Giladi M, Kletter Y, Avidor B, Metzkor-Cotter E, Varon M, Golan Y, et al. Enzyme immunoassay for the diagnosis of cat-scratch disease defined by polymerase chain reaction. Clin Infect Dis. 2001;33:1852-8. http://dx.doi.org/10. $1086 / 324162$

15. Metzkor-Cotter E, Kletter Y, Avidor B, Varon M, Golan Y, Ephros M, et al. Long-term serological analysis and clinical follow-up of patients with cat scratch disease. Clin Infect Dis. 2003;37:1149-54. http://dx.doi.org/10.1086/378738
16. La Scola B, Raoult D. Serological cross-reactions between Bartonella quintana, Bartonella henselae, and Coxiella burnetii. J Clin Microbiol. 1996;34:2270-4.

17. Raoult D, Fournier PE, Drancourt M, Marrie TJ, Etienne J, Cosserat J, et al. Diagnosis of 22 new cases of Bartonella endocarditis. Ann Intern Med. 1996;125:646-52. http://dx.doi.org/10.7326/0003-4819-125-8-199610150-00004

18. Johnson G, Ayers M, McClure SCC, Richardson SE, Tellier R. Detection and identification of Bartonella species pathogenic for humans by PCR amplification targeting the riboflavin synthase gene (ribC). J Clin Microbiol. 2003;41:1069-72. http://dx.doi.org/10.1128/JCM.41.3.1069-1072.2003

19. Baddour LM, Wilson WR, Bayer AS, Fowler VG Jr, Tleyjeh IM, Rybak MJ, et al.; American Heart Association Committee on Rheumatic Fever, Endocarditis, and Kawasaki Disease of the Council on Cardiovascular Disease in the Young, Council on Clinical Cardiology, Council on Cardiovascular Surgery and Anesthesia, and Stroke Council. Infective endocarditis in adults: diagnosis, antimicrobial therapy, and management of complication. A scientific statement for healthcare professionals from the American Heart Association. Circulation. 2015;132:1435-86. http://dx.doi.org/10.1161/CIR.0000000000000296

20. Baltimore RS, Gewitz M, Baddour LM, Beerman LB, Jackson MA, Lockhart PB, et al.; American Heart Association Rheumatic Fever, Endocarditis, and Kawasaki Disease Committee of the Council on Cardiovascular Disease in the Young and the Council on Cardiovascular and Stroke Nursing. Infective endocarditis in childhood: 2015 update. A scientific statement from the American Heart Association. Circulation. 2015;132:1487-515. http://dx.doi.org/10.1161/CIR.0000000000000298

21. Rolain JM, Brouqui P, Koehler JE, Maguina C, Dolan MJ, Raoult D. Recommendations for treatment of human infections caused by Bartonella species. Antimicrob Agents Chemother. 2004;48:1921-33. http://dx.doi.org/10.1128/AAC.48.6.19211933.2004

22. Houpikian P, Raoult D. Western immunoblotting for Bartonella endocarditis. Clin Diagn Lab Immunol. 2003;10:95-102.

23. Spach DH, Callis KP, Paauw DS, Houze YB, Schoenknecht FD, Welch DF, et al. Endocarditis caused by Rochalimaea quintana in a patient infected with human immunodeficiency virus. J Clin Microbiol. 1993;31:692-4.

24. Daly JS, Worthington MG, Brenner DJ, Moss CW, Hollis DG, Weyant RS, et al. Rochalimaea elizabethae sp. nov. isolated from a patient with endocarditis. J Clin Microbiol. 1993;31:872-81.

25. Raoult D, Fournier PE, Vandenesch F, Mainardi JL, Eykyn SJ, Nash J, et al. Outcome and treatment of Bartonella endocarditis. Arch Intern Med. 2003;163:226-30. http://dx.doi.org/10.1001/ archinte.163.2.226

26. Ohl ME, Spach DH. Bartonella quintana and urban trench fever. Clin Infect Dis. 2000;31:131-5. http://dx.doi.org/10.1086/313890

27. Marié JL, Fournier PE, Rolain JM, Briolant S, Davoust B, Raoult D. Molecular detection of Bartonella quintana, B. elizabethae, B. koehlerae, B. doshiae, B. Taylorii, and Rickettsia felis in rodent fleas collected in Kabul, Afghanistan. Am J Trop Med Hyg. 2006;74:436-9.

28. Kernif T, Leulmi H, Socolovschi C, Berenger JM, Lepidi H, Bitam I, et al. Acquisition and excretion of Bartonella quintana by the cat flea, Ctenocephalides felis. Mol Ecol. 2014;23:1204-12. http://dx.doi.org/10.1111/mec.12663

29. Fournier PE, Lelievre H, Eykyn SJ, Mainardi JL, Marrie TJ, Bruneel F, et al. Epidemiologic and clinical characteristics of Bartonella quintana and Bartonella henselae endocarditis: a study of 48 patients. Medicine (Baltimore). 2001;80:245-51. http://dx.doi.org/10.1097/00005792-200107000-00003

30. Balakrishnan N, Menon T, Fournier PE, Raoult D. Bartonella quintana and Coxiella burnetii as causes of endocarditis, India. 
Emerg Infect Dis. 2008;14:1168-9. http://dx.doi.org/10.3201/ eid1407.071374

31. Fournier PE, Mainardi JL, Raoult D. Value of microimmunofluorescence for diagnosis and follow-up of Bartonella endocarditis. Clin Diagn Lab Immunol. 2002;9:795-801.

32. Edouard S, Nabet C, Lepidi H, Fournier PE, Raoult D. Bartonella, a common cause of endocarditis: a report on 106 cases and review. J Clin Microbiol. 2015;53:824-9.

http://dx.doi.org/10.1128/JCM.02827-14

33. Sangaré AK, Boutellis A, Drali R, Socolovschi C, Barker SC, Diatta G, et al. Detection of Bartonella quintana in African body and head lice. Am J Trop Med Hyg. 2014;91:294-301. http://dx.doi.org/10.4269/ajtmh.13-0707

34. Cutler S, Abdissa A, Adamu H, Tolosa T, Gashaw A. Bartonella quintana in Ethiopian lice. Comp Immunol Microbiol Infect Dis. 2012;35:17-21. http://dx.doi.org/10.1016/ j.cimid.2011.09.007

\section{May 2016: Vectorborne Diseases}

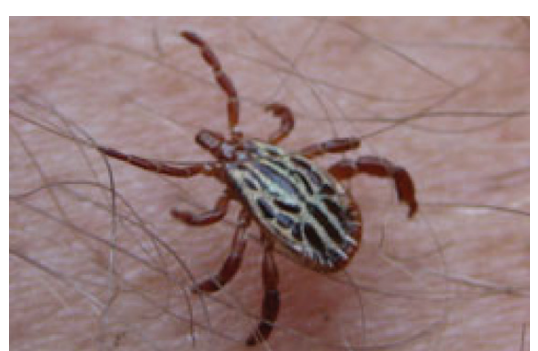

- An Operational Framework for Insecticide Resistance Management Planning

- Rickettsia parkeri Rickettsiosis, Arizona, USA

- Plasmodium falciparum K76T pfcrt Gene Mutations and Parasite Population Structure, Haiti,

- Outbreak of Middle East Respiratory Syndrome at Tertiary Care Hospital, Jeddah,

Saudi Arabia, 2014

- Expansion of Shiga ToxinProducing Escherichia coli by Use of Bovine Antibiotic Growth Promoters

- Acute Human Inkoo and Chatanga Virus Infections, Finland

- Differences in Genotype, Clinical Features, and Inflammatory Potential of Borrelia burgdorferi sensu stricto Strains from Europe and and the United States

- Projecting Month of Birth for At-Risk Infants after Zika Virus Disease Outbreaks
- Genetic Characterization of Archived Bunyaviruses and Their Potential for Emergence in Australia potential.

- Plasmodium falciparum In Vitro Resistance to Monodesethylamodiaquine, Dakar, Senegal, 2014

- Astrovirus MLB2, a New Gastroenteric Virus Associated with Meningitis and Disseminated Infection

- Spectrum of Viral Pathogens in Blood of Malaria-Free III Travelers Returning to Canada

- Expanded Geographic Distribution and Clinical Characteristics of Ehrlichia ewingii Infections, United States

- Molecular Characterization of Canine Rabies Virus, Mali, 2006-2013

- Fatal Monocytic Ehrlichiosis in Woman, Mexico, 2013

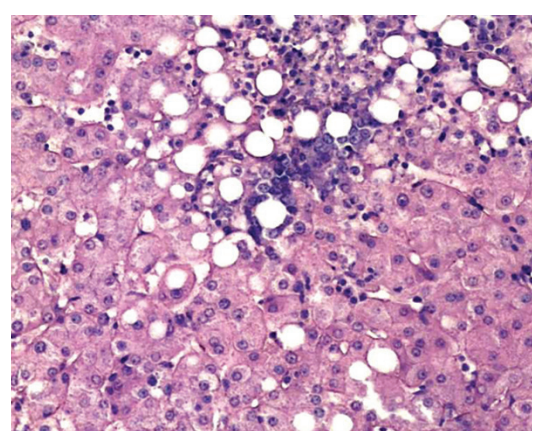

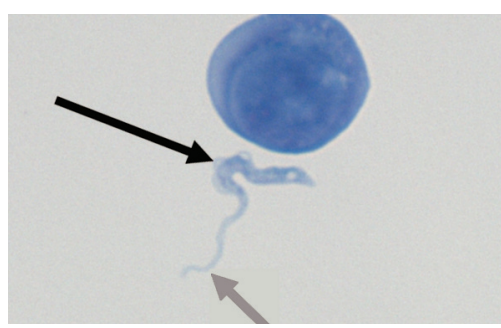

- Increased Rotavirus Prevalence in Diarrheal Outbreak Precipitated by Localized Flooding, Solomon Islands, 2014

- Rickettsia sibirica mongolitimonae Infection, France, 2010-2014

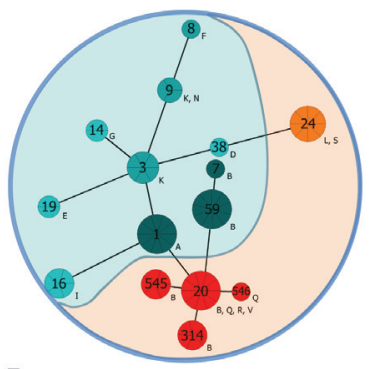

- Q Fever, Scrub Typhus, and Rickettsial Diseases in Children, Kenya, 2011-2012

- Molecular Characterization of Chikungunya Virus, Philippines, 2011-2013

- Severe Sepsis and Septic Shock Associated with Chikungunya Virus Infection, Guadeloupe, 2014

- Cutaneous Leishmaniasis and Conflict in Syria

\section{EMERGING} INFECTIOUS DISEASES

\section{https://wwwnc.cdc.gov/eid/articles/ issue $/ 22 / 5 /$ table-of-contents}

